\title{
Використання діагностичної цінності ознак якості ґрунту при його екологічному контролі
}

\author{
Н.О. Любимова
}

\author{
Харківський національний аграрний університет ім. В.В. Докучаєва \\ (м.Харків, Україна) етаil: nina.lioubimova@gmail.com, ORCID: 0000-0001-8964-7326
}

Дане дослідження присвячене питанням можливості вирішення задачі інтегрованого керування якістю землі при організації його контролю з метою виконання норм природокористування та прогнозованого вирішення завдань отримання максимального урожаю, стратегічного керування технологічними процесами для зменшення дегуміфрікації, організації земельного кадастру та упорядкуванню землі в умовах сільськогосподарського упорядкування.

Стратегічний напрямок використання земельних ресурсів у перспективі визначає його подальший характер використання, вибір сівозмін, застосування оптимальних технологічних процесів, строків висіву та збору урожаю, тощо... Необхідною ланкою для цього є контроль якості проведених польових робіт, фрізичних, хімічних та біологічних показників антропогенного впливу.

Запропонована математична модель для можливості діагностики об'єкту контролю та отриманням у подальшому узагальнюючих показників його якості (грунту). Розглядається діагностична цінність ознак (показники хімічного та фізичного стану землі, результати оцінки якості обробітку, хімічної меліорації, якості робіт по удобренню, проведеної сівби, застосування гербіцидів, проведення перевірки якості заходів боротьбі із шкідниками, збиральних робіт тощо), розробка аналітичних залежностей критеріїв, із можливістю діагностики об'єкту та отриманням у подальшому узагальнюючих показників якості контролю. Експериментальні дані отримують згідно нормативним вимогам у визначені строки.

Проведена постановка діагнозу при вірогіднісних методах розпізнавання наступна. Побудоване вирішальне правило, за допомогою котрого, сукупність ознак, що діагностується, віднесена до одного із можливих станів (діагнозів). Оцінена вірогідність прийнятного рішення та ступінь ризику помилкового рішення. Кількісне визначення діагностичної цінності окремої ознаки, комплексу ознак або узагальнюючих ознак проведено на основі теорії інформації . Діагностична цінність ознак визначається долею кількості інформації, що привнесена цією ознакою в систему розпізнавання стану. Більшість ознак (складні) при оцінюванні стану грунтів визначають наявність ряду градацій - діагностичні інтервали, так як завжди можливо кількісно чітко з'ясувати, як пороги.

Отримані результати дослідження можливо використати для формалізації оцінки стану грунтів з метою впорядкування землеустрою і кадастру, вирішення загальних діагностичних задач стратегічного та поточного корегування і поліпшення якості землі для отримання ефективних і оптимальних рішень покращення урожайності за умови виконання екологічного законодавства.

Ключові слова: екологія, модель, контроль, прогнозування, багатокомпонентне забруднення.

Проблеми контролю, обліку, економічного використання народно - господарських та природних ресурсів стали першочерговими для вирішення на державному рівні. За останні роки Кабінетом Міністрів України прийнято ряд постанов, що спрямовані на розробку, впровадження у виробництво та вдосконалення більш досконалої методології та організації контролю в галузі регулювання витрат енергії, води та раціонального використання сільськогосподарських грунтів.

Контроль - найважливіша складова з усіх сфер суспільного виробництва. Від її професійного вирішення суттєво залежить ефективність та якість проведення технологічних та природних процесів. За відсутністю системи інтегрованого керування використанням природних ресурсів
України збитки за останні роки дуже збільшились. У зв'язку із цим Верховною Радою України запропонований комплекс заходів, що спрямований на вдосконалення системи моніторингу для оцінки впливу антропогенних чинників на довкілля, забезпечення екологічного контролю та виконання екологічних нормативів викидів та скидів речовин, що забруднюють атмосферу, гідросферу, літосферу та біосферу. Для оцінки стійкості екосистем (літосфери) використовують поняття екологічного резерву. Це різниця між гранично допустимим відхиленням та фактичним станом екосистеми. Вона вказує на розміри тієї буферної зони, в межах якої можливі неруйнівні зміни [1- 3].

Кожні 10 років людство втрачає близько 7\% верхнього шару землі внаслідок ерозії, що 
заподіяна природними або антропогенними впливами. Характер деградаційних тенденцій ґрунтоутворення в екологічному аспекті досить прозоро діагностується [4].

Дегуміфікація $€$ одним 3 найхарактерніших супутників нераціонального використання грунту в аграрному виробництві. На Україні оперативний контроль стану природних об'єктів (атмосфери, гідросфери та літосфери) потребує великих матеріальних витрат. На сьогоднішній день недостатньо розвинуті комплексні математичні моделі для контролю, оцінки та подальших стратегічних рішень для збереження та відновлення родючості сільськогосподарських грунтів $[4,5]$. Тому виникає задача розробки нових більш досконалих методів та засобів, що дозволяють вирішити протиріччя між інформаційним забезпеченням систем контролю грунту та економічними витратами на їх забезпечення без втрат якості контролю.

Метою роботи $€$ теоретичне обгрунтування методів та засобів контролю якості грунту при вирішенні проблеми контролю багатофакторних антропогенних впливів шляхом побудови математичної моделі, розробка аналітичних залежностей критеріїв, із можливістю діагностики та отриманням у подальшому узагальнюючих показників якості об'єкту контролю.

Об'єктом дослідження є якісні показники фрізичних, хімічних та біологічних процесів, що впливають на стан грунту в умовах антропогенного навантаження, що необхідно для виконання вимог норм природокористування.

Предметом дослідження, вивчення та впливу при виконанні екологічного моніторингу $€$ фрізичні, хімічні та біологічні процеси, які впливають на стан грунту.

Постановка задачі. Для побудови математичної моделі в задачі діагностики природного об'єкту (грунту) необхідно отримати сукупність масивів апріорної інформації із встановленням стану згідно показників, що регламентуються нормами природокористування. Це можуть бути показники хімічного та фрізичного стану землі, результати оцінки якості обробітку, хімічної меліорації, якості робіт по удобренню, проведеної сівби, застосування гербіцидів, проведення перевірки якості заходів боротьбі із шкідниками, збиральних робіт...

Запропоновані рішення. Для оцінки якості проведених технологічних операцій з метою оптимізації фрізичного та хімічного стану грунту, що характеризується структурно-агрегатним складом, щільністю, загальною та диференційованою шпаруватістю, водоутримуючою здатністю і показниками механічних властивостей використовують головні кількісні регламентні показники, що мають важливе значення для нормального розвитку рослин [1,4].
Експериментальні дані отримують згідно нормативним вимогам у визначені строки. Від якісного контролю таких показників, їх подальшої обробки та корекції технологічних операцій залежить і кінцевий результат - отриманий урожай. Потрібно своєчасно ідентифікувати стан грунту та виробляти стратегічні засади, використання певних сільськогосподарських технологій для його оптимального функціонування та отримання високого врожаю.

Контроль природних об'єктів (грунту, води, повітря) протікає в умовах багатозв'язності, динамічності, багатопараметричності, нестаціонарності та інших особливостей. Він повинен своєчасно ідентифікувати стан, дозволяти оперативно формувати та надавати технологічні впливи, що його корегують.

В задачах діагностики стан природної системи описують за допомогою комплексу ознак

$$
K=\left(k_{1}, k_{2}, \ldots k_{j}, \ldots k_{\mu}\right),
$$

де $\quad k_{j}$ - ознака, що має $\mu_{j}$ разрядів.

Фактично, стан грунту, що спостерігається, збігається із визначеною реалізацією ознаки та позначається верхнім індексом $\left(^{*}\right)$. В загальному випадку стан грунту співпадає із визначеною реалізацією ознаки. Наприклад, стан грунту із пониженою величиною щільності визначаємо як

$$
K_{j}^{*}=k_{j 3} .
$$

В загальному випадку поточний стан грунту визначається як реалізація комплексу ознак

$$
K^{*}=\left(k_{1}^{*}, k_{2}^{*}, \ldots k_{j}^{*}, \ldots k_{\mu}^{*}\right) .
$$

В цьому плані в багатьох алгоритмах розпізнавання стану грунту можливо характеризувати систему параметрів $x_{j}$, що утворює $\eta$ - мірний вектор або точку в $\eta$ - мірному просторі

$$
x=\left(x_{1}, x_{2}, \ldots x_{j}, \ldots x_{\eta}\right) .
$$

В більшості випадків параметри $x_{j}$ мають безперервний розподіл, тоді як опис ознаки $k_{j}-$ може бути представлений в дискретній формі.

В екологічній та технічній діагностиці всі можливі стани системи, що досліджуються - діагнози - вважають за відомі. Однак, для опису об'єкту використовують два основні підходи в завданні розпізнавання стану, що контролюється: вірогіднісний та детерміністичний.

Постановка діагнозу при вірогіднісних методах розпізнавання наступна.

Система, що спостерігається, знаходиться в одному із $n$ випадкових станів $D_{j}$. Відома сукупність ознак (параметрів), кожен із котрих із визначеною вірогідністю характеризує стан системи. Потрібно побудувати вирішальне правило, за 
допомогою котрого, сукупність ознак, що діагностується, буде віднесена до одного із можливих станів (діагнозів). Бажано також оцінити вірогідність прийнятого рішення та ступінь ризику помилкового рішення.

Кількісне визначення діагностичної цінності окремої ознаки, комплексу ознак або узагальнюючих ознак може бути проведено на основі теорії інфрормації $[7,8]$. Головний принцип цього підходу полягає в наступному: діагностична цінність ознак визначається долею кількості інформації, що привнесена цією ознакою в систему розпізнавання стану. Ознаки поділяються на прості та складні [8,9]. Більшість ознак (складні) у нашому випадку при оцінюванні стану грунтів визначають наявність ряду градацій - діагностичні інтервали, так як їх завжди можливо кількісно чітко з'ясувати, як пороги.

Потрібно визначити діагностичну вагу ознаки $k_{j}$, яка має для даного стану грунту $k_{j i}$ - реалізацію ознаки $k_{j}$. Визначимо її як $k_{j}^{*}$, будемо мати $k_{j}^{*}=k_{j s}$.

В цьому випадку в якості діагностичної ваги реалізації ознаки $k_{j}$ для діагнозу $D_{i}$ приймаємо співвідношення [9]

$$
Z_{D}\left(k_{j}^{*}\right)=Z_{D}\left(k_{j s}\right)=\log \frac{P\left(D_{i} / k_{j s}\right)}{p\left(D_{i}\right)},
$$

де $\quad P\left(D_{i} / k_{j s}\right)-$ вірогідність діагнозу $D_{i}$ за умови, що ознака вимірювання $k_{j}$ отримала значення $k_{j s} ; P\left(D_{i}\right)$ - апріорна вірогідність діагнозу. Величина $Z_{D}\left(k_{j s}\right)$ - цінність інформації - з точки зору теорії інформації уявляє собою інформацію про стан об'єкту $D_{i}$ (грунту), котрий має стан ознак $k_{j s}[7]$.

Якщо вірогідність стану об'єкту $D_{i}$ після того, як з'ясувалось , що ознака $k_{j}$ має реалізацію в інтервалі $s$, збільшилась $\left[P\left(D_{i} / k_{j s}\right)>P\left(D_{i}\right)\right]$, то $Z_{D}\left(k_{j s}\right)>0$. Тобто, діагностична вага даного інтервалу ознаки для даного діагнозу додатна. У випадку, якщо наявність параметру на інтервалі $s$ не змінює вірогідність діагнозу, то отримуємо межу для діагнозу

$Z_{D}\left(k_{j s}\right)=0, \quad$ так як $\quad\left[P\left(D_{i} / k_{j s}\right)=P\left(D_{i}\right)\right]$

Діагностична вага інтервалу $s$ ознаки $k_{j}$ по відношенню до діагнозу $D_{i}$ у третьому випадку може бути заперечною (заперечення діагнозу).

Діагностичну вагу наявності ознаки $k_{j}$ в інтервалі $s$ можливо записати у такому вигляді, більш зручному для конкретних розрахунків [8-10].

$$
Z_{D}\left(k_{j}\right)=\log _{2} \frac{P\left(k_{j s} / D_{i}\right)}{P\left(k_{j s}\right)},
$$

де $P\left(k_{j s} / D_{i}\right)$ - вірогідність появи інтервалу $s$ ознаки $k_{j}$ для об'єктів із діагнозом $D_{i}$; $P\left(k_{j s}\right)$ - вірогідність появи цього інтервалу у всіх об'єктів із різними діагнозами.

Еквівалентність рівнянь (1) і (2) витікає із наступного рівняння

$$
P\left(k_{j s}\right) P\left(D_{i} / k_{j s}\right)=P\left(D_{i}\right) P\left(k_{j s} / D_{i}\right)=P\left(k_{j s} / D_{i}\right) .
$$

Одним із головних напрямків використання запропонованого підходу $€$ проблема оцінки стану грунтів в екологічному моніторингу. Серед двох основних завдань $є$ установлення діагнозу та контроль стану складних систем. Перше завдання пов'язане із проблемою розпізнавання образів [8,9]. Питання діагностики та прогнозування розглядаються [9 -10].

При математичній постановці задачі діагностування необхідно використовувати методи задачі розпізнавання образу як задачі відновлення функції, що розділяє із найменшим ризиком [9]. Ця задача достатньо складна сама по собі, а тому задача відновлення на практиці стає майже умовною. Математична теорія інформації із ії основними положеннями суттєво впливає на формалізацію задач діагностичних проблем, в котрих одним із напрямків $є$ оцінка діагностичної цінності [9] в тому числі і для оцінки стану грунтів.

\section{Висновок.}

Отримані результати дослідження можливо використати для формалізації оцінки стану грунтів з метою впорядкування землеустрою і кадастру, вирішення загальних діагностичних задач стратегічного та поточного корегування і поліпшення якості землі для отримання ефективних i оптимальних рішень покращення урожайності.

\section{Література}

1. ДСТУ ISO 11074-1:2004 Якість грунту. Словник термінів. Частина 1. ISO 11074-1:1996. Забруднення та охорона грунтів.

2. ДСТУ ISO 11074-2:2004 Якість грунту. Словник термінів. Частина 2.

3. ДСТУ ISO 11074-4:2004 Якість грунту. Словник термінів. Частина 4.

4. Тихоненко Д.Г. Грунтознавство: Підруч. Для вузів. - К.: Вища освіта, 2005. - 703 с.

5. Надточій П.П. Екологія грунту та його забруднення // П.П. Надточій, В.Г.Гермашенко, Ф.В. Вольвач // К.: 2011, - 170 с.

6. Руденко А.О. Основи екології // А.О. Руденко // Миколаїв, 2011, - 210 с.

7. Сайко В.Ф. Довідник по визначенню якості польових робіт // В.Ф. Сайко, А.М. Малієнко, М.В. Коломієць та інші. // К.: Урожай, 1987. - 120 с.

8. Гроп Д. Методі идентификации систем // Д. Гроп // Пер с англ.. В.А. Васильева. - М.: Мир. 1997. - 302 c. 
9. Биргер И.А. Определение диагностической ценности признаков // И.А. Биргер // М.: Кибернетика № 3, 1998, - С. 80-85.

10. Биргер И.А Техническая діагностика // И.А. Биргер // М.: Машиностроение, 1998. - 240 с.

\section{Referenc}

e

1. DSTU ISO 11074-1: 2004 Yakist soil. Glossary of terms. Part 1. ISO 11074-1: 1996. Soil protection and soil protection.

2. DSTU ISO 11074-2: 2004 Yakist soil. Glossary of terms. Chastina 2.

3. DSTU ISO 11074-4: 2004 Yakist soil. Glossary of terms. Chastina 4.

4. Tikhonenko, D. (2005). Gruznozavstvo. Kyiv: Vishcha osvita, p. 703.
5. Nadtochiy, P., Germashenko, V. and Volvach, F. (2011). Ecology of the ground and that of yogh obstruction. Kyiv, p. 170.

6. Rudenko, A. (2011). Fundamentals of Ecology. Mikolaev, p. 210.

7. Saiko, V., Malinko, A., Kolomiets, M., Degodiuk, E., Fischenko, U., Grytsaj, A., Mazur, G., Simachynskyi, V., Lysenko, A., Kornijchuk, M., Andriuschenko, A. and Kravchenko, L. (1987). Dovidnik po viznachennyu yakosti polovih robit. Kyiv: Urozhaj, p. 120.

8. Graupe, D. (1976). Identification of systems. Huntington, N.Y.: R.E. Krieger Pub. Co., p. 287.

9. Birger, I. (1998). Determination of the diagnostic value of signs. Cybernetics, (3), pp. $80-85$.

10. Birger, I. (1998). Technical diagnostics. Moscow: Mechanical Engineering, p. 240.

\section{Аннотация}

\section{Использование диагностической ценности признаков качества грунта при его екологическом контроле}

\section{Н.А. Любимова}

Данное исследование посвящено вопросам возможности решения задачи интегрированного управления качеством земли при организации его контроля с целью выполнения норм природопользования и прогнозируемого решения задач получения максимального урожая, стратегического управления технологическими процессами для уменьшения дегумификации, организации земельного кадастра и упорядочению земли в условиях сельскохозяйственного упорядочения.

Стратегическое направление использования земельных ресурсов в перспективе определяет его дальнейший характер использования, выбор севооборотов, применения оптимальных технологических процессов, сроков посева и сбора урожая, и тому подобное ... Необходимым звеном для этого является контроль качества проведенных полевых работ, физических, химических и биологических показателей антропогенного воздействия.

Предложенная математическая модель для возможности диагностики объекта контроля и получением в дальнейшем обобщающих показателей его качества (почвы). Рассматривается диагностическая ценность признаков (показатели химического и фризиеского состояния земли, результаты оценки качества обработки, химической мелиорации, качества работ по удобрению, проведенной сева, применение гербицидов, проведение проверки качества мероприятий борьбе с вредителями, уборочных работ и т.п.), разработка аналитических зависимостей критериев, с возможностью диагностики объекта и получением в дальнейшем обобщающих показателей качества контроля. Экспериментальные данные получают согласно нормативным требованиям в определенные сроки.

Проведена постановка диагноза при вероятностных методах распознавания следующая. Построенное решающее правило, с помощью которого, совокупность признаков, диагностируется, отнесена к одному из возможных состояний (диагнозов). Оценена вероятность приемлемого решения и степень риска ошибочного решения. Количественное определение диагностической ценности отдельного признака, комплекса признаков или обобщающих признаков проведено на основе теории информации. Диагностическая ценность признаков определяется судьбой количества информации, привнесенная этому признаку в систему распознавания состояния. Большинство признаков (сложные) при оценке состояния почв определяют наличие ряда градаций - диагностические интервалы, так как всегда возможно количественно четко выяснить, как пороги.

Полученные результаты исследования возможно использовать для фрормализации оценки состояния почв с целью упорядочения землеустройства и кадастра, решения общих диагностических задач стратегического и текущего корректировки и улучшения качества земли для получения эффрективных и оптимальных решений улучшения урожайности при условии выполнения экологического законодательства.

Ключевые слова: экология, модель, контроль, прогнозирование, многокомпонентное загрязнение.

ISSN 2311-1828

http://enm.khntusg.com.ua
Інженерія природокористування, 2019, №4(14), с. 86 - 90

Engineering of nature management, 2019, \#4(14), p. 86 - 90 


\section{Abstract \\ Use of diagnostic value of signs of soil quality at its ecological control

\author{
N.O. Lyubymova
}

This study addresses the possibility of solving the problem of integrated land quality management in the organization of its control in order to meet environmental standards and predictive tasks of obtaining maximum yield, strategic management of technological processes to reduce dehumidification, organization of land cadastre and ordering the land in terms of agricultural management.

The strategic direction of land resources use in the future determines its further nature of use, selection of crop rotations, application of optimal technological processes, terms of seeding and harvesting, etc. ...

The necessary link for this is the quality control of field work, physical, chemical and biological indicators of anthropogenic impact.

A mathematical model is proposed for the possibility of diagnosing a control object and further generalizing its quality (soil). Diagnostic value of features (indicators of chemical and physical state of the earth, results of estimation of quality of cultivation, chemical reclamation, quality of works on fertilization, sowing, application of herbicides, carrying out quality control of measures of pest control, harvesting works, etc.), development of analytical dependencies of criteria, is considered the ability to diagnose the object and obtain further generalizations of the quality of control. The experimental data are obtained according to the regulatory requirements within the specified time limits.

The diagnosis at the probabilistic methods of recognition is as follows. A decisive rule is constructed by which the set of diagnosed features is assigned to one of the possible conditions (diagnoses). The likelihood of a decision being made and the degree of risk of a wrong decision are estimated. The quantitative determination of the diagnostic value of an individual trait, complex of traits or generalizations is based on information theory

The diagnostic value of a trait is determined by the fraction of the amount of information that the trait brings to the status recognition system. Most features (difficult) in assessing the condition of soils determine the presence of a number of gradations - diagnostic intervals, as it is always possible to quantify clearly how thresholds are.

The results of the study can be used to formalize the assessment of soil conditions in order to streamline land and cadastre, solve common diagnostic problems of strategic and ongoing adjustment and improve the quality of land to obtain effective and optimal solutions for improving yields.

Keywords: ecology, model, control, forecasting, multicomponent, pollution

\section{Бібліографрічне посилання/ Bibliography citation: Harvard}

Lyubymova N. (2019). Use of diagnostic value of signs of soil quality at its ecological control. Engineering of nature management, (4(14), pp. 86 - 90.

Подано до редакції / Received: 09.12.2019 